\title{
The Identification of Opportunities for Innovations through Collecting Problems from Citizens
}

\author{
Karine Oganisjana * and Konstantins Kozlovskis \\ Faculty of Engineering Economics and Management, Riga Technical University, Riga LV-1658, Latvia; \\ konstantins.kozlovskis@rtu.lv \\ * Correspondence: karine.oganisjana@rtu.lv
}

Received: 7 July 2019; Accepted: 22 September 2019; Published: 26 September 2019

\begin{abstract}
Customer engagement in different phases of creation of new products and services is argued to be a significant success factor by some scholars and practitioners, and unnecessary-by others. The paper analyses the findings of a pilot study, conducted with the intention to see whether ordinary citizens from different countries could highlight problems which really could bring forth ideas for innovative products or services. The data were collected via electronic survey with the further qualitative content analyses of the problems that, to the respondents' minds, are worth solving. The expert group analysis of the ideas which derived from the problems was conducted to decide the feasibility of the approach, whose efficiency was concluded not to be high. Reliability and consistency of the experts' assessments were tested using statistical software SPSS 20 based on the correlation analysis of five criteria-usefulness, social impact, customer base, frequency of use, and novelty. The research revealed 16 groups of problems.
\end{abstract}

Keywords: citizen engagement; problem derived innovation; innovation opportunities; bank of problems

\section{Introduction}

It is argued that prospective innovations begin as problems or ideas which flow along the action pathway, getting developed through stages such as opportunity recognition, development, realization, and learning [1]. The very first stage which is called opportunity identification [2], opportunity creation [3], or opportunity development [4] is crucial, as it drives, gives meaning to, and directs all the processes for creating new value. Whether the opportunity identification be a top-down or bottom-up process is becoming a topical issue being discussed by scholars [5]. Opinions on the importance of customer engagement in the creation and development of innovative ideas, products, and services contradict each other, as they bring to light both positive and negative effects of customer engagement [6-8]. The majority of scholars emphasize the important role of customers in giving insight into their needs, and in the co-thinking and co-creating, thus directing the actions of companies towards useful innovation and new value creation [9-14]. However, there are also opponents to this point of view who show various drawbacks of customer engagement in different stages of new product development. One of them is overemphasis on customers' feedback in the design process, which might make an enterprise reactive rather than proactive while attempting to produce solutions to meet every customer's needs regardless of the cost [15]. Gavin Symanowitz criticizes the practice of asking customers for big ideas. Instead, he appeals that innovators and companies should think for themselves and build their brands through creating great products they believe people will love; "Want a great new idea? Don't ask your customers" [16] (p. 24). 
In order to decide whether so called the "wisdom of crowds" [17] could be relevant power for revealing innovation opportunities through collecting problems from citizens of different countries, the authors of this article answered the following two research questions:

(1) What kind of problems do citizens consider to be worth solving that could create new innovation opportunities?

(2) How reasonable is the approach of collecting problems from citizens for identifying innovation opportunities?

\section{Why to Create a Bank of Problems: The Theoretical Background of the Research}

Literature analysis shows that customer engagement in new product and service development could be characterized by two main concepts which justify the approach of creating a bank of problems for generating new valuable ideas.

- Ideas which might bring about valuable innovation could be given by customers-just ordinary people who might be pivotal sources of knowledge and whose participation helps translate their needs into new products $[6,9-11,13,14,18-20]$.

- When there are problems and needs, people are forced to invent ways for solving them. That means, a problem-driven approach may always bring to some useful ideas and innovation opportunities [6,21-23]. Useful ideas for innovation in this paper are understood as ideas for such innovations which meet people's needs and do not cause negative externalities that result in social costs out weighing the private gains [24].

\subsection{Customer Engagement}

Today it is becoming trendy to engage customers in new product development by companies not only because it is a question of style, but because it is mutually beneficial. Using the criterion of customer engagement, Forbes divides companies into two categories-leaders of customer engagement and followers [25]. Speaking about the mutual good, the Forbes states:

"Those who lead engage customers with a purpose, offer consistent experiences, analyze customer data, and structure their teams in such a way that the customer takes priority. But having happier customers isn't the only benefit leaders see. They also see an improved bottom line with higher retention, faster growth, and less churn. It's a trend these days for companies to say they're customer-centric" [25] (p. 1).

The 50 most engaged USA companies ranked by the Forbes have their market value (MV) measured in tens of billions (B) of dollars and their annual growth (AG) measured, with the highest reaching 41.7\%. Among them are Amazon.com, Inc. (MV—\$427.0B; AG-27.1\%); Alphabet Inc. Class A (MV— \$579.5B; AG—20.4\%); Starbucks Corporation (MV—\$84.6B; AG—11.2\%); Adobe Systems Incorporated (MV—\$64.4B; AG—22.1\%); $E^{*}$ TRADE Financial Corporation (MV—\$9.6B; AG—41.7\%); General Motors Company (MV— $\$ 50.8 \mathrm{~B}$; AG—9.2\%); and others who consider customer engagement as one of their success factors [25].

The findings by numerous studies conducted in different business fields indicate multiple positive effects and advantages of the combination of service/product users and providers' resources for the creation of new value. Customer engagement in the co-creation, development, and promotion of new products and services increases customer's trust, brand loyalty, awareness, understanding, motivation, and close interactions with producers, which enhance the competitive advantage of the new valuable in the market [26-28]. It is a complex task. As concluded by Altinay and colleagues, in order to create trust and develop long-term relationships with customers, companies must create a sense of affinity, emphasizing different cultural tiles to different customer groups who might perceive things differently despite the shared language, ethnicity, religion, and common identity [29].

Customer engagement is a key aspect of open innovation which implies that valuable ideas can come to a company and the market both internally and externally [30]. Customer engagement is 
related to the concepts of user innovation, customer innovation, collective intelligence, crowdsourcing, and open source innovations, and all of them are referred to as open innovation, as they are innovation which is based on the transfers across the boundaries of knowledge and technology [31]. In favor of open innovation, the findings of research conducted by Jinhyo Joseph Yun and colleagues revealed that those companies which prefer efficiency-based hierarchical structures, rather than horizontal, creativity-centered structures in decision-making, in order to maximize the efficiency and speed up the development of new and diverse product lines, may face challenges, and even fail in the market [32]. This phenomenon can be explained by the argument that, "Closed innovation can fail to draw the right conclusions from the information successively revealed about the implications of an innovation. The more open the innovation process is, the more likely it is in contrast that an innovation be abandoned when there are hints pointing at a failure" [24].

Being one of the stakeholders of open innovation, consumers collectively play several roles in the value co-creation process, such as:

- Co-producer;

- Co-distributor;

- Co-promoter;

- Co-manufacturer;

- Co-consumer;

- Experience creator;

- Innovator;

- Co-ideator;

- Co-evaluator;

- Co-tester;

- Co-designer [10].

Minna Oinonen analyzed, systemized, and characterized four modes for customer engagement: (1) passive engagement, (2) sales-based engagement, (3) customer insight, expert-based engagement, and (4) customer orientation as an organizational mindset. For the realization of these four modes, correspondingly, four sets of typical practices of customer engagement were suggested: (1) reclamations, customer feedback, and customer surveys; (2) customer surveys, market research, and sales visits; (3) customer visits, interviews, observation, and workshops; and (4) a combination of all [20]. The previously mentioned customer's roles systemized by Agrawal \& Rahman [10] can be distinguished in these four sets of typical practices. For example, in a typical practice of feedback and surveying, customers play the role of co-evaluators; in reclamations-the role of co-evaluators and co-testers; in the market research — the role of co-ideators and co-evaluators; in workshops-the role of co-innovators, co-ideators, and co-designers, etc. Thus, though these two research cases explored different aspects of customer engagement; the conclusions are in line with each other.

However, as has already been mentioned, there are also radically opposite points of view related to the role of customers in the value creation process of companies and the ways the "customer-company" interaction is organized. Gavin Symanowitz levels criticism against focus group discussions as a typical practice for getting customer feedback and contributions in different phases of new product development, as:

- Some people, who have stronger personalities than others, certainly influence the opinions of others;

- For those with more submissive personalities it is difficult to express an opinion which goes against the group consensus;

- A number of people often talk at once, thus some people's views are lost and cannot be explored properly;

- Participants often say what they think the sponsors want to hear; 
- Some people give politically correct answers, which may not honestly represent their views;

- Facilitators may subconsciously encourage answers which are not frank but convenient;

- A facilitator might be 'fishing for sound bites' that would look good on the final report, rather than aiming for a deep understanding of the underlying issues;

- It is not reasonable to spend millions for developing a new product approved by a committee because six of the eight people in a focus group liked the idea [16].

It is difficult to disagree with this standpoint, especially if the effectiveness of such expensive practices is not high and if they may cause serious risks to the development of valuable new products and services. It speaks of the significance of exploring and revealing more effective customer engagement approaches.

Bob Kijkuit and Jan van den Ende suggest the development of a dynamic framework for social networks to bridge the idea generation with a selection of ideas and projects. They ground their approach by putting forward the following argument: on the one hand, the existing theories of the influence of social networks on creativity, focus on idea generation. On the other hand, the new product development literature concentrates more on the selection of ideas and projects. Therefore, they decided to integrate these two processes in one [19].

The authors of this paper used research projects with the involvement of Master's students within a university study course on research to get access to people living in different regions of the world, and to collect data on their needs and problems faced, their views of how these problems could be solved, and what products and services could be created as a result. Thus, this approach makes people's voices be heard and used for creating new, useful ideas without investing any financial resources. Such research projects have a doubly positive effect, as, on the one hand, students' learning efforts are used for the good of the society: they collect data, analyze ongoing processes, and elaborate solutions and innovation ideas which could be used by entrepreneurs. On the other hand, they perceive the learning process not as a formalized act which is far away from real life problems and situations, but as a process closely linked to what takes place in the world of business and research.

\subsection{Defining the Right Problem}

Henrik Florén and colleagues argue that although new product development projects tend to fail in different stages, the underlying causes of failure can often be traced to the very earliest stage, called the front end of new product development [6]. As concluded by La Verne Abe Harris, the biggest mistake people make when creating new ideas comes from putting a lot of energy and resources into trying to solve the wrong problem, thus wasting all their resources and innovation power. Therefore, the very first thing in the process of innovation should be to take the time to define the right problem that needs to be solved [21]. Speaking of the creation of new opportunities for innovation in products, services, processes, and business models, Massimo Garbuio Dan Lovallo and colleagues emphasize that the best solutions are achieved by observing situations involving user behavior or user-generated problem statements [22]. More and more, as argued by Alawattari, the focus is shifted from the importance of the "newness" of products and services to the importance of their ability to solve problems or deliver a real benefit compared to existing products or solutions, as just being new is not good enough [23].

Therefore, in innovation projects it is crucial to identify such ideas which carry problem-solving potential. As concluded by Robert Cooper and his colleagues, the qualities of the initial idea typically "make or break the project," thus underlining the pivotal role of the very initial ideas in the further development of new products and services [33] (p. 22).

Moreover, the authors of this paper acknowledge the significance of spotting viable initial ideas for new product and service development. For increasing the commercialization potential, practical utility, and value of new products and services, the ideas should derive from people's needs and problems. That is the reason why the authors suggest creating a bank of problems, collecting them from ordinary citizens, and analyzing them in order to light the sparks of innovative ideas and fuel an innovative mind. This approach has been practiced by Karine Oganisjana since 2011 in work with: (a) 
secondary school students and their teachers [34], (b) university students [35], and (c) an international teachers' group within the Erasmus+ project IRIS, Developing Functional Creativity: from Words to Actions! 2016-2018.

\section{The Course of the Research and the Main Findings}

The research was conducted in Riga Technical University (RTU) in the autumn semester of 2018. The research methods used were:

- Literature analysis for revealing the role of problem identification in the pre-stage of innovative-idea creation and determining criteria for evaluating the innovation potential of ideas derived from the problems;

- An electronic survey for qualitative and quantitative data collection;

- Qualitative content analysis of the texts of respondents' replies for revealing the scopes of problems which were considered to be worth solving;

- An expert group analysis of the ideas which derived from the problems highlighted in the survey;

- Statistical analyses of the quantitative data for testing reliability and consistency of the experts' assessments and for comparing the levels of the problems' topicalities, evaluated by the respondents themselves and the expert group.

The data were collected by the Latvian and international Master's students within the study course "Modern Research Methods: Theory and Practice," under the supervision of Karine Oganisjana. Having elaborated and piloted a questionnaire in Latvian and English, the Master's students sent it to their acquaintances who live in different countries with a request to share just one problem, which they consider to be worth solving for creating new value. The questionnaire had a special instruction combined with a short illustrative material, which explained the importance of changing our attitude towards problems, from perceiving them as hindrances or disasters, to considering them as interesting situations and sources of new opportunities [36]. This thought was shown with the example of the "Silicone Spill Stopper Lid Cover" [37], providing it with the analysis of all the problems which that particular lid solves at once. Along with demographic information about respondents' age, gender, country of living, education, and profession, the respondents were expected to share one problem related to any aspect of their life: household (bedroom, living room, kitchen, bathroom, furniture, different things we use in everyday life, etc.), human body and health care, economy, environment, education, leisure, sports, or politics; or ones concerning children, seniors, people with special needs, etc. The respondents were asked also to explain, in their opinion, how topical the problem is, how it could be solved, and what kind of products or services could be created as a result. The problems were expected to be very concrete and specified instead of common, well-known ones, like a polluted environment, unemployment, high prices, inequality, corruption, etc.; especially if they were not able to provide their own ideas on how to solve them or what products or services could be created.

The data were collected mainly from Latvia $(n=219)$, India $(n=88)$, Pakistan $(n=39)$, Azerbaijan $(n=28)$, Sri-Lanka $(n=21)$, and Finland $(n=9)$ - the native countries of the Master's students. Although there were respondents also from other countries (43 respondents from 23 countries). Out of 495 survey answer sheets 48 were ignored, as they either were not fully filled in or the content was not understandable, most likely due to the difficulties the respondents experienced because of writing in English-a language which is not native to them. Subsequently, 443 valid answer sheets made the bank of problems for joint use by all the Master's students. As data collection is a crucial part of research, it was agreed that each Master's student had to provide 10 respondents to get the corresponding experience and to create a joint data base. For monitoring the data collection process and seeing how many responses were provided from each student, the questionnaire ended with the request to indicate the name of the student who organized the survey of each respondent. As the Google electronic spreadsheets were shared and sent to all the students, they had the access to all the information to analyze the quality of the answers and to find other respondents if needed. 


\subsection{Qualitative Content Analysis: Problems that Citizens Consider to Be Worth Solving}

In the course of the qualitative content analysis of the texts written by the respondents in their answers to the question "What problem do you consider to be worth solving?" The following 16 categories of problem groups were developed:

(1) Self-organization related problems, like: dissatisfaction with one's work, forgetfulness and lack of concentration of attention, poor management of one's own time and work, challenges of self-motivation, difficulties in undertaking activities needed for personal growth, etc.

(2) Business related problems: low levels of employee motivation, low wages, the absence of care from employees, the poor quality of products and services, the absence of specific types of businesses, etc.

(3) Government administration related problems encompassing general and global issues which require the intervention of various kinds of governmental structures: imperfect social welfare and legal guardianship, corruption, the low efficiency of governmental structures, the poor greening of territories throughout the country, problems in labor market, problems of public administration (medicine, health care, education, public safety, etc.), racism, social inequality, electoral issues, taxation systems, etc.

(4) Ecology/environment related problems: all types of pollution (caused by light, odor, or noise), air, soil, and water pollution, challenges of waste and plastic recycling, sorting out of all types of garbage, lack of clean drinking water, etc.

(5) Engineering problems requiring the creation of some mechanisms or technical improvements for overcoming issues, like: heat leakage, food preservation, the inconvenience of using tools and things like bags, garbage bins, buckets, and cutting tools, the tangling of cords, loss of small keys and small gadgets, etc.

(6) Medicine/healthcare related problems: alcoholism, psychological disorders, food unsafety, issues of physical and mental health, hygiene issues, etc.

(7) Legislation problems related to: the creation of new legislation system or the need for improvement of the already existing one, gender inequality, homophobia, needs in creation of new system of election, different issues of nationwide level, etc.

(8) Education related problems caused by its low quality and imperfections: the inconsistency of the quality of education for the needs of business, laziness and lack of student motivation, poor financial literacy, traditions and prejudices of particular parts of the society or sub-cultures concerning education, cultural peculiarities which do not favor education.

(9) Transport related problems, like the deregulation of traffic schedules and the need for its optimization, issues related to dirt in public transport, violations of traffic safety rules, etc.

(10) Information technology problems that are directly related to electronics and software, like the creation of computer and mobile applications, Internet security, cyber security and protection, problems of electronic voting, etc.

(11) Science/technology related problems that require scientific research in relevant areas. For example, the need for the creation of new materials and new technologies for solving practical issues of different natures.

(12) Household problems which are to be overcome in the course of routine everyday activities, like cutting fingers or burning hands while cooking, fogging up glass, the frequent tearing of lady tights, the need for insect/pest control, failures of water circulation in the house, etc.

(13) Recycling problems related to sorting and recycling of all kinds of garbage and wastes: plastic, household appliances, harmful materials, and equipment, etc.

(14) Economic problems affecting macroeconomics and different sectors/industries, such as: inflation, unemployment, high interest rates, consumers' negative attitudes and dissatisfaction with the quality and prices of products and services, etc. 
(15) Municipality-administration problems which require the intervention of municipalities or municipal structures: failures of public transport, the lack or inexistence of public toilets, the cleaning and taking care of public territories, etc.

(16) Infrastructure related problems requiring: the creation of a new, or improved version of an already existing road and railway infrastructure, the disposal of traffic congestion, ensuring traffic safety, etc.

The diagram depicted in Figure 1 reveals how frequently each problem group was mentioned by the respondents.

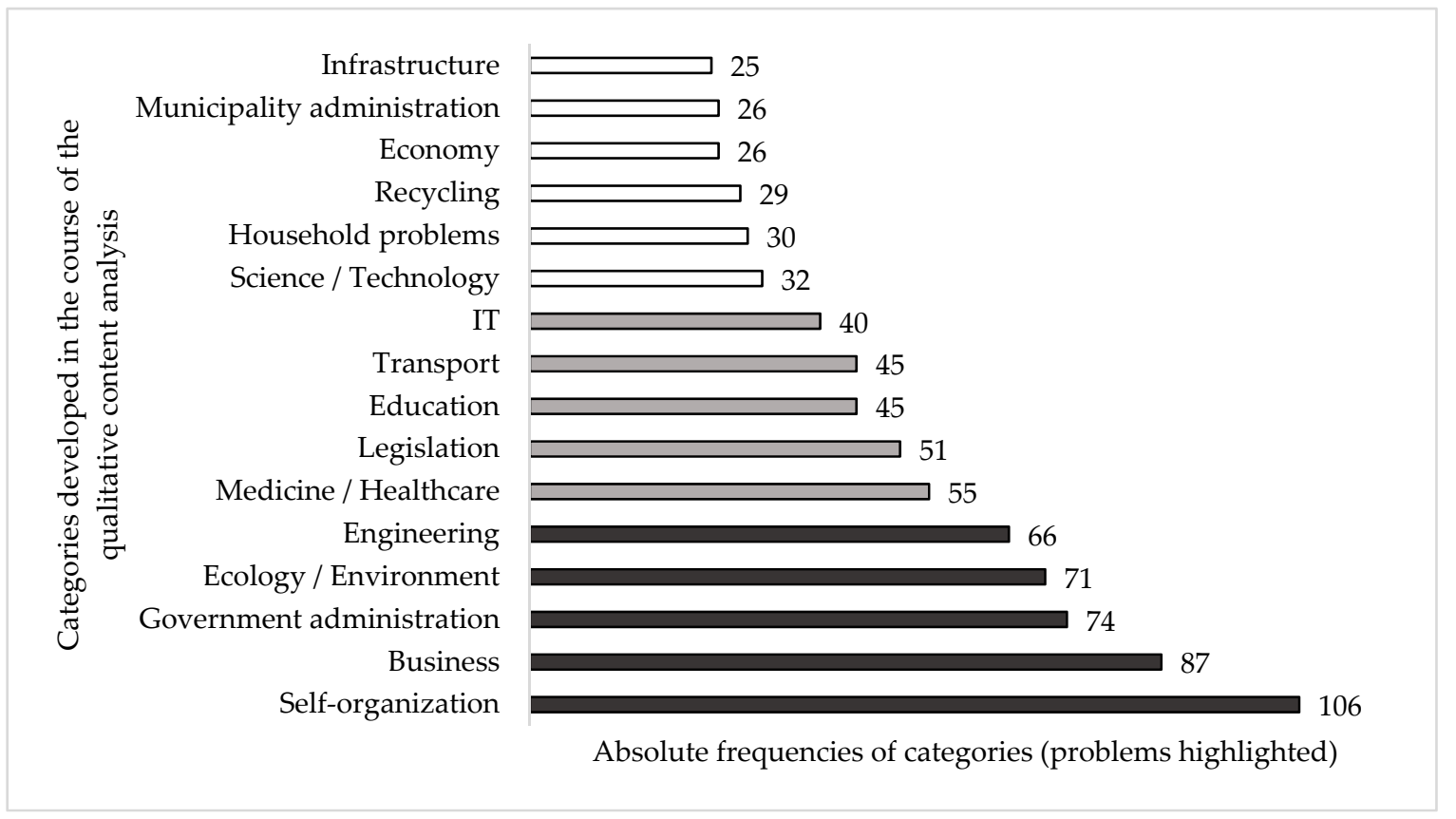

Figure 1. Distribution of the problem groups by the frequencies they were spoken about.

The leader among the problems is self-organization $(n=106)$ which means that in our dynamically changing world of high technologies, despite all modern conveniences, people seriously face challenges when organizing themselves and get lost in the flow of events and information. They need help. Therefore, the most needed are those innovations which help people to become more organized, concentrated and motivated. This diagram reflects the distribution of the absolute frequencies of the problems put forward for solving by all the respondents representing different regions of the world. The distribution would be different for each region or country taken separately, as topicalities and urgent problems and their weights in Latvia, for instance, differ from the ones in India. As the number of the respondents from each region or country was not big enough to make a representative scope, comparative analysis among the regions was not conducted in this research but is planned for further investigation. In this stage, three clusters of problems were determined. The first cluster shows that after the self-organization, business, government administration, environmental, and engineering related problems led the topicality ratings of the problems. This seems surprising, as closer to the front edge of the first cluster, we expected to see majority of the problems of the third cluster: household, municipality administration, recycling and economy related problems, as these are problems which people come across every day and are regularly impacted by. This division into clusters in the stage of piloting is relative; it was done just for revealing the character of the problems and the tendencies of their topicalities. The main emphasis was put on the creation of the bank of problems and feasibility analysis of such an approach for the boosting creation of innovation ideas to decide whether this practice should be expanded and developed on or not. It must be emphasized that majority of the 
respondents did not offer worthy solutions to their problems. Nevertheless, some problems themselves gave food for thought and innovation ideas.

To give insight into the character of the problems collected, two examples will be considered below. One of the respondents mentioned the problem of bad smell in public transport, and as a solution, he proposed the insertion of two small ionizers in both ends of a bus; for a few minutes the ionizers are to be turned on, and then go back of. Such a solution could be reasonable after thorough research of all the air parameters changed in the course of an ionizer's operation in different modes. Another respondent wrote that for her, it is an unpleasant procedure to change the plastic bag of the garbage bin in her kitchen, as each time, she has to bend to reach the bottom of her high garbage bin. There was not any solution from her. But that problematic scenario gave rise to the idea of a new garbage bin design. If a special space is built under a garbage bin for fixing a roll of plastic bags to be pulled inside through a cut-out on the bottom of the garbage bin, then each time, by removing a full garbage bag, it will pull up the next garbage bag to the top of the garbage bin.

Several problems showed that some respondents were not aware that solutions to their problems already exist. Despite being warned, some of the respondents wrote about such general problems, like unemployment, high prices, inequality, etc. without giving any ideas for overcoming them.

\subsection{Expert Group Analysis: The Feasibility of Collecting Problems from Citizens for Identifying Innovation Opportunities}

In order to decide whether this approach to new opportunity recognition is reasonable, a group of three experts in business and entrepreneurship worked together in the following order:

(1) First, the experts analyzed the answer sheets independently, concentrating their attention on each respondent's answers to the three questions: (a) What problem do you consider to be worth solving? (b) How should this problem be solved in your opinion? (c) What kind of product or service could be created as a result? The focus was on new products and services which could be created to solve these problems and could carry commercialization potential in themselves.

(2) Then the experts discussed each problem and finalized their decisions, assigning joint points using the following five criteria:

- Usefulness (benefits, advantages, and the good that consumers and companies could get by using the new product/service without causing negative externalities that result in social costs out weighing the private gains);

- Social impact (the effect that the new product/service might have on the well-being of the community as a whole, its economy, culture, or environment);

- Customer base (the range of potential users whom that new product/service might be related to);

- Frequency of use (how often the new product/service is going to be consumed by potential users);

- Novelty (the quality of being new and unusual of the product/service-to-be).

These criteria were elaborated based on La Verne Abe Harris' concepts of evaluating innovative ideas analyzed in "Idea Engineering: Creative Thinking and Innovation" [21]. Potential product/service ideas were assessed from the perspective of each of these criteria using a five-point system:

$5=$ very high;

$4=$ somewhat high;

$3=$ neutral;

2 = somewhat low;

$1=$ low. 
Those problems which were not provided with a solution or a product/service idea, were not taken into consideration. The best problems and best ideas were filed separately for further analysis, with the intention of creating solutions to them.

The points assigned were summed up for each idea and then divided by five to determine their average values. That value indicates the innovation potential of an idea. The bigger the average, the higher the innovation potential.

The ideas were organized into five value ranges depending on the averages of the assessments: "From 0 to 1", "From 1 to 2", "From 2 to 3", "From 3 to 4", and "From 4 to 5".

The problems and the ideas derived from them whose average assessment varied "From 0 to 1 " and "From 1 to 2 " were considered to not have much chance of bringing about innovation. Innovation potential is high for the range of average values: "From 3 to 4 " and "From 4 to 5". However, some so-called "food for thought" ideas could be found within the range of average assessments "From 2 to 3." Figure 2 shows the number of problems within each range of average values.

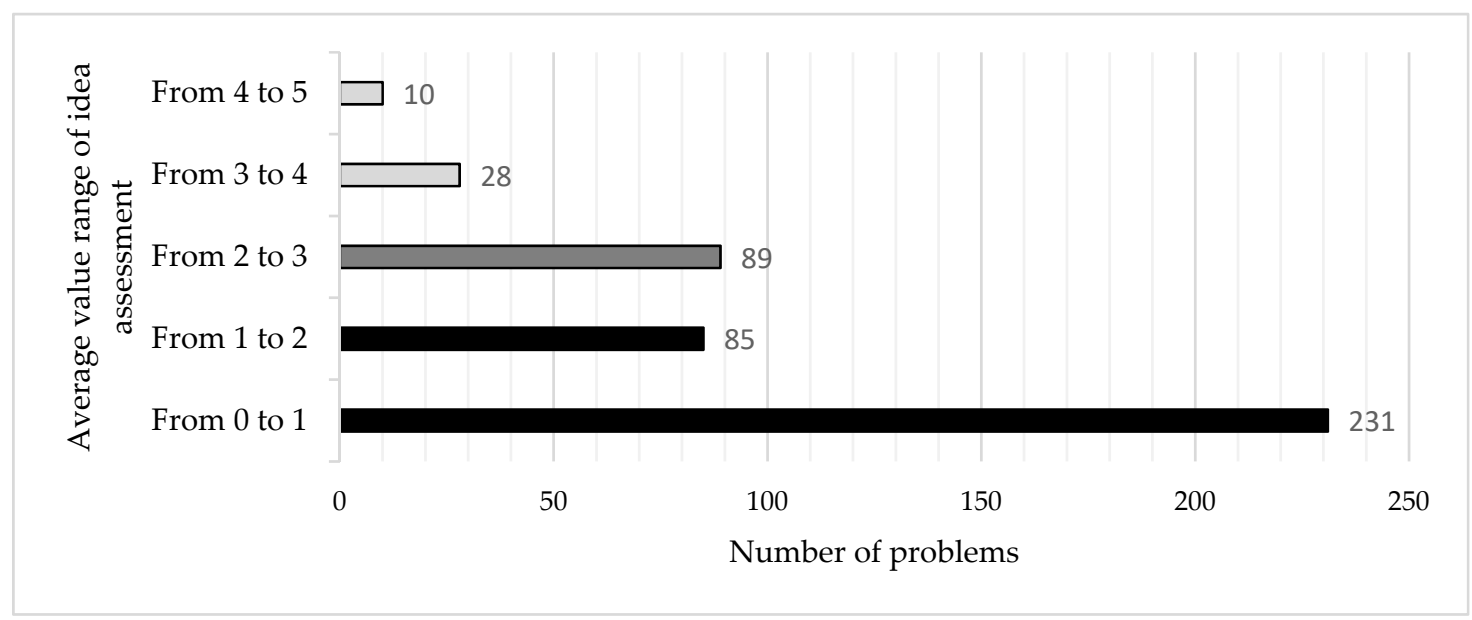

Figure 2. Distribution of the numbers of problems by the ranges of their average values.

The diagram in Figure 2 shows that the bulk of the problems $(89+85+231=405)$, which make up $91.42 \%$ of all the problems, were of low innovation potential or no innovation potential at all. Only 38 problems (see the bars "From 3 to 4 " and "From 4 to 5 " in Figure 2) were worth considering. Thus, the proportion of "good problems" was below $9 \%(38 / 443=8.58 \%)$. Nevertheless, the authors' assessment of this outcome is positive, taking into account three aspects:

- That was a learning research project for Master's students, within which they acquired good practical research experience related to identification and creation of innovation ideas;

- Some of the Master's students and the authors received inspiring ideas for further development;

- This experience did not require any financial investments.

\subsection{Statistical Analysis: The Reliability and Consistency of the Experts' Assessment}

After the experts' assessment of all the problems and innovation ideas which could be extracted from them, it was then analyzed whether their assessments were reliable and synchronized.

Question 1: Do the five criteria (usefulness, social impact, customer base, frequency of use, and novelty) correlate with each other?

The correlation analysis of the values of these five criteria was conducted using statistical software SPSS 20. Because of the limited values from one to five, the correlation analysis was based on the Spearman's correlation coefficient. As shown in Table 1, all Spearman's correlation coefficients were positive and very close to one, signaling an almost perfectly linear relationship between the five criteria. 
Table 1. The results of correlation analysis of the five criteria.

\begin{tabular}{|c|c|c|c|c|c|c|c|}
\hline & & & Usefulness & $\begin{array}{l}\text { Social } \\
\text { Impact }\end{array}$ & $\begin{array}{c}\text { Customer } \\
\text { base }\end{array}$ & $\begin{array}{l}\text { Frequency } \\
\text { of Use }\end{array}$ & Novelty \\
\hline \multirow{10}{*}{$\begin{array}{l}\text { Spearman's } \\
\text { rho }\end{array}$} & \multirow{2}{*}{ Usefulness } & $\begin{array}{l}\text { Correlation } \\
\text { Coefficient }\end{array}$ & 1.000 & 0.966 & 0.934 & 0.924 & 0.960 \\
\hline & & Sig. (2-tailed) & & 0.000 & 0.000 & 0.000 & 0.000 \\
\hline & \multirow{2}{*}{$\begin{array}{l}\text { Social } \\
\text { impact }\end{array}$} & $\begin{array}{l}\text { Correlation } \\
\text { Coefficient }\end{array}$ & 0.966 & 1.000 & 0.945 & 0.924 & 0.943 \\
\hline & & Sig. (2-tailed) & 0.000 & & 0.000 & 0.000 & 0.000 \\
\hline & \multirow{2}{*}{$\begin{array}{l}\text { Customer } \\
\text { base }\end{array}$} & $\begin{array}{l}\text { Correlation } \\
\text { Coefficient }\end{array}$ & 0.934 & 0.945 & 1.000 & 0.944 & 0.914 \\
\hline & & Sig. (2-tailed) & 0.000 & 0.000 & & 0.000 & 0.000 \\
\hline & \multirow{2}{*}{$\begin{array}{l}\text { Frequency } \\
\text { of use }\end{array}$} & $\begin{array}{l}\text { Correlation } \\
\text { Coefficient }\end{array}$ & 0.924 & 0.924 & 0.944 & 1.000 & 0.903 \\
\hline & & Sig. (2-tailed) & 0.000 & 0.000 & 0.000 & & 0.000 \\
\hline & \multirow[t]{2}{*}{ Novelty } & $\begin{array}{l}\text { Correlation } \\
\text { Coefficient }\end{array}$ & 0.960 & 0.943 & 0.914 & 0.903 & 1.000 \\
\hline & & Sig. (2-tailed) & 0.000 & 0.000 & 0.000 & 0.000 & \\
\hline
\end{tabular}

Moreover, all the correlation coefficients obtained in this analysis were statistically significant at $95 \%$ and even $99 \%$ probability level significance $=0<0.05$ ). Thus, the experts' assessments were closely related to each other: a higher value of one criterion was supported by higher values of the other ones.

Question 2. Is there consistency between the assessments of the experts?

The consistency of experts' assessments according to the five criteria was analyzed based on the reliability analysis, using a strict parallel model. As seen in Table 2, the intraclass correlation coefficient was very high (single measures $=0.887$; average measures $=0.975$ ), positive, and statistically significant at the $95 \%$ probability level (significance $=0<0.05$ ).

Table 2. Intraclass correlation coefficient of experts' assessments.

\begin{tabular}{cccccccc}
\hline & \multirow{2}{*}{$\begin{array}{c}\text { Intraclass } \\
\text { Correlation }\end{array}$} & \multicolumn{2}{c}{ 95\% Confidence Interval } & \multicolumn{3}{c}{ F Test with True Value 0 } \\
\cline { 3 - 8 } & Lower Bound & Upper Bound & Value & df 1 & df2 & Sig \\
\hline Single Measures & 0.887 & 0.871 & 0.902 & 40.291 & 446 & 1784 & 0.000 \\
\hline $\begin{array}{c}\text { Average } \\
\text { Measures }\end{array}$ & 0.975 & 0.971 & 0.979 & 40.291 & 446 & 1784 & 0.000 \\
\hline
\end{tabular}

Considering the results of correlation analysis and reliability analysis of the five criteria (usefulness, social impact, customer base, frequency of use, and novelty) used for the assessment of innovation ideas which derived from the problems collected, it can be concluded that the experts' assessments were reliable, appropriate, and consistent. That means, the higher the innovation level of an idea, the higher its assessment given by the experts.

3.4. Statistical Analysis: The Differences between the Experts' and Respondents' Assessments of the Topicalities of the Problems Highlighted

The topicalities of the problems were assessed both by the respondents themselves and the experts using a six-point system:

5 - extremely topical;

4 -very topical;

3-topical;

2-somewhat topical;

1 -rather not topical than topical; 
0—not topical.

Question 3: Are there any differences between the experts' assessments and respondents' assessments of the topicalities of the problems highlighted?

The consistency of experts' assessments and respondents' assessments was analyzed based on reliability analysis, using a strict parallel model. Table 3 shows that the intraclass correlation coefficient was average (single measures $=0.279$; average measures $=0.436$ ), positive, and statistically significant at the $95 \%$ probability level (significance $=0<0.05$ ).

Table 3. Intraclass correlation coefficient of respondents' assessments and experts' assessments.

\begin{tabular}{cccccccc}
\hline & \multicolumn{9}{c}{ Intraclass Correlation Coefficient } \\
& $\begin{array}{c}\text { Intraclass } \\
\text { Correlation }\end{array}$ & \multicolumn{2}{c}{$\mathbf{9 5 \% \text { Confidence Interval }}$} & \multicolumn{3}{c}{ F Test with True Value 0 } \\
\cline { 3 - 8 } & & Lower Bound & Upper Bound & Value & df1 & df2 & Sig. \\
\hline Single Measures & 0.279 & 0.191 & 0.362 & 1.773 & 446 & 446 & 0.000 \\
\hline $\begin{array}{c}\text { Average } \\
\text { Measures }\end{array}$ & 0.436 & 0.321 & 0.532 & 1.773 & 446 & 446 & 0.000 \\
\hline
\end{tabular}

Therefore, there was a certain inconsistency between the respondents' and the experts' assessments of the topicalities of the problems. In order to analyze the details of the inconsistency, histogram-based analysis and a mean comparison by the Kolmogorov-Smirnov test were conducted.

Figure 3 displays two separate histograms of respondents' and experts' assessments of the level of the problems' topicalities.

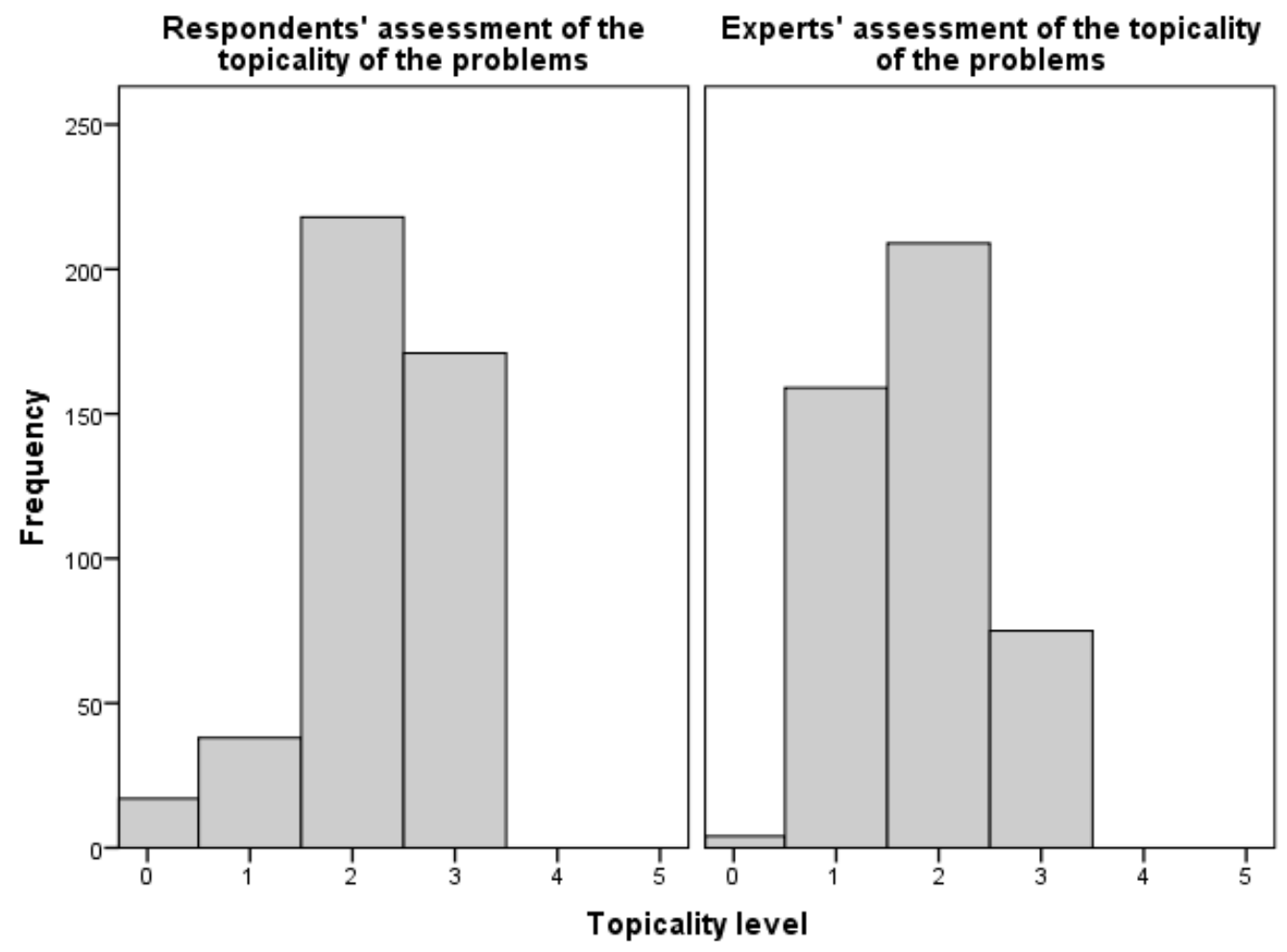

Figure 3. Histograms of topicalities of the problems assessed by the respondents and the experts.

The distributions significantly differed:

- The total number of problems assessed as " 1 " by the respondents was smaller than from the experts;

- Controversially, the total number of problems assessed as " 3 " by the respondents was greatly larger than by the experts; 
- the frequencies of problems assessed as " 2 " by the respondents and the experts were almost the same.

Conducting the Kolmogorov-Smirnov test for comparing the differences between respondents' and experts' assessments, the null hypothesis of the equality of two means was rejected, because the $p$-value (significance) was zero, which is lower than commonly accepted level of 0.05 (see Table 4).

Table 4. Results of Kolmogorov-Smirnov test.

\begin{tabular}{ccc}
\hline \multicolumn{2}{c}{ Test Statistics } & Topicality \\
\hline \multirow{3}{*}{ Most Extreme Differences } & Absolute & 0.241 \\
\cline { 2 - 3 } & Positive & 0.241 \\
\cline { 2 - 3 } & Negative & -0.029 \\
\hline Kolmogorov-Smirnov Z & 3.594 \\
\hline \multicolumn{2}{c}{ Asymp. Sig. (2-tailed) } & 0.000 \\
\hline
\end{tabular}

Thus, the assessment by the respondents and experts differed statistically significantly at the $95 \%$ probability level. Calculating the means of the assessments carried out by the respondents and experts, it was concluded that on average the respondents overvalued the topicalities of their problems (the mean was 2.22) in comparison with the experts' opinions (the mean was 1.79).

\section{Discussion and Conclusion}

Our findings suggest that it is reasonable to practice the approach of boosting innovation-opportunity identification through the collection of problems from ordinary citizens for several reasons. First of all, their problems and their solutions contain the potential for usefulness, which shifts the accent from the "newness" of innovation ideas to their power to satisfy customers' needs and solve problems which was actualized by Alwattari [23].

Secondly, surveys organized in the way piloted in Riga Technical University (RTU) are free of the drawbacks of costly and not always efficient focus group discussions criticized by Symanowitz [16]. In the survey, the respondents acted independently, without anybody else's impact on their mind, and at their own pace. In addition, they did not experience any of the embarrassment of speaking in front of others and did not try to please anybody with certain ideas. No financial resources are invested in such research projects! However, the authors do not consider such electronic surveys to be the best solution, as the quality of responses was not always high; the survey was unanimous and in some cases the respondents answered the questions formally just to get rid of the work and help their friends or relatives; those were the RTU Master's students who organized their survey. Therefore, it was decided to improve the method of the organization of the survey to provide better outcomes. The mechanism of getting ten respondents from each Master's student will be complemented with the quality analysis of the data obtained. This research gave one "right problem" out of 11 , which is less than $9 \%(8.58 \%)$. To get more "right problems," as they were termed by La Verne Abe Harris [21], it has been decided first to educate the respondents with a number of innovative products and services, indicating the problems which they solve. In the questionnaire of this research, there was only one example, the "Silicone Spill Stopper Lid Cover" [37], which solves multiple problems. One example might not be enough for changing people's attitudes to problems and starting to see the innovation potential in them. In the autumn semester of the academic year 2019-2020, the research will be continued by other Master's students with an improved questionnaire. A comparative analysis of problems provided by different demographic groups will be conducted as well; the data of the two years will be summed up to make more representative scopes. The principle, "one citizen-one problem" will be followed on, as respondents should concentrate all their efforts on one problem without dissipating their attention. 
Despite the imperfections, this approach is suitable for student research, as in the course of the university studies, the students did not just learn about research methods and methodology, but practiced them within a real research project passing through all its stages. The students developed their research skills. Some of them became inspired by the discoveries they made in the course of the research and became more motivated to start their own businesses. The authors consider that the findings of such study research could be of interest to entrepreneurs, university staff, and students, for creating innovative products and services for commercialization.

It has also been decided to specify different respondent groups (women, seniors, people with special needs, families with more than three children, etc.) in the further research cases to get sector-specific problems for elaborating innovation ideas for peculiar target groups.

The problems highlighted by the respondents covered all the aspects of human life; that shows that people are concerned about a broader range of global problems than mainly about the ones which are related to them personally. It was curios to reveal that on average, the respondents tended to overvalue the topicalities of their problems (the mean was 2.22) in comparison with the experts' opinions (the mean was 1.79). This could be explained by: (1) different levels of education, experience, development, and awareness of the respondents and the experts; (2) the psychological aspects of human nature to exaggerate the importance of things created by them (the respondents), and to be stricter and more critical speaking about things created by others (the expert group). Still, this is just supposition which should be investigated to have more evidence and a scientific basis for the explanation.

As to the methodology for the analysis by the expert group, both the correlation analysis and reliability analysis of the five assessment criteria (usefulness, social impact, customer base, frequency of use, and novelty) revealed reliability, appropriateness, and consistency (intraclass correlation 0.975 ; significance $=0<0.05$ ) of the experts' assessments. The statistically significant correlation coefficient and intraclass correlation coefficient proved a strong relationship between the five criteria, showing that they are appropriate tools for the assessment of ideas which could be extracted from the problems collected.

These judgments allowed us to make conclusions to answer both research questions.

Research question 1: What kind of problems do citizens consider to be worth solving for creating new innovation opportunities?

The citizens shared problems which encompass all the aspects of human life, the environment, science, and technology:

(1) Self-organization related problems $(n=106)$;

(2) Business related problems $(n=87)$;

(3) Government administration related problems $(n=74)$;

(4) Ecology/environment related problems $(n=71)$;

(5) Engineering related problems $(n=66)$;

(6) Medicine/healthcare related problems $(n=55)$;

(7) Legislation related problems $(n=51)$;

(8) Education related problems $(n=45)$;

(9) Transport related problems $(n=45)$;

(10) Information technology related $(n=44)$;

(11) Science/technology related problems $(n=32)$;

(12) Household related problems $(n=30)$;

(13) Recycling related problems $(n=29)$;

(14) Economy related problems $(n=26)$;

(15) Municipality administration related problems $(n=26)$;

(16) Infrastructure related problems $(n=25)$.

Research question 2: How reasonable is the approach of collecting problems from citizens for identifying innovation opportunities? 
Since problem identification and formulation are both challenging, expensive, time consuming, and complex procedures, which demand the concentration of attention and multiple experiences from different groups of people, this approach is appropriate and beneficial from the perspectives of: (1) collecting problems for boosting ideas for innovative products and services without any investments of financial resources; (2) enhancing the practical value of studies in university; (3) linking university studies to entrepreneurship and real business life; and (4) promoting students' research skills.

Author Contributions: K.O. and K.K. contributed equally in all the stages of the development of this research paper. Funding: This research received no external funding.

Acknowledgments: The paper is to disseminate the findings of research conducted within the Erasmus + project IRIS, Developing Functional Creativity: from Words to Actions!

Conflicts of Interest: The authors declare no conflict of interest.

\section{References}

1. O'Sullivan, D.; Lawrence, D. Applying Innovation; SAGE Publications, Inc.: Los Angeles, CA, USA, 2009.

2. Baron, R.A. Opportunity Recognition as Pattern Recognition: How Entrepreneurs "Connect the Dots" to Identify New Business Opportunities. Acad. Manag. Perspect. 2006, 20, 104-119. [CrossRef]

3. Sarasvathy, S.; Dew, N.; Venkataraman, S. Three Views of Entrepreneurial Opportunity. In Handbook of Entrepreneurship Research; Acs, Z., Audretsch, D., Eds.; Kluwer Academic Publishers: Dordrecht, The Netherlands, 2003; pp. 141-160.

4. Sanz-Velasco, S.A.; Sanz-Velasco, S.A. Opportunity development as a learning process for entrepreneurs. Int. J. Entrep. Behav. Res. 2006, 12, 251-271. [CrossRef]

5. Saari, E.; Lehtonen, M.; Toivonen, M. Making bottom-up and top-down processes meet in public innovation. Serv. Ind. J. 2015, 35, 325-344. [CrossRef]

6. Florén, H.; Johan Frishammar, J.; Parida, V.; Joakim Wincent, J. Critical success factors in early new product development: A review and a conceptual model. Int. Entrep. Manag. J. 2018, 14, 411-427. [CrossRef]

7. Fang, E. Customer Participation and the Trade-Off between New Product Innovativeness and Speed to Market. J. Mark. 2008, 72, 90-104. [CrossRef]

8. Peled, M.; Dvir, D. Towards a contingent approach of customer engagement in defense projects: An exploratory study. Int. J. Proj. Manag. 2012, 30, 317-328. [CrossRef]

9. Hult, G.T.M.; Morgenson, F.V.; Morgan, N.; Mithas, S.; Fornell, C. Do managers know what their customers think and why? J. Acad. Mark. Sci. 2017, 45, 37-54. [CrossRef]

10. Agrawal, A.K.; Rahman, Z. Roles and Resource Contributions of Customers in Value Co-creation. Int. Strat. Manag. Rev. 2015, 3, 144-160. [CrossRef]

11. Kumar, V. Evolution of Marketing as a Discipline: What Has Happened and What to Look Out For. J. Mark. 2015, 79, 1-9. [CrossRef]

12. Majchrzak, A.; Malhotra, A. Towards an information systems perspective and research agenda on crowdsourcing for innovation. J. Strat. Inf. Syst. 2013, 22, 257-268. [CrossRef]

13. Vargo, S.L.; Lusch, R.F. Evolving to a New Dominant Logic for Marketing. J. Mark. 2004, 68, 1-17. [CrossRef]

14. Prahalad, C.K.; Ramaswamy, V. The Future of Competition: Co-Creating Value with Customers; Harvard Business School Press: Boston, MA, USA, 2004.

15. Ittner, C.D.; Larcker, D.F. Product Development Cycle Time and Organizational Performance. J. Mark. Res. 1997, 34, 13. [CrossRef]

16. Symanowitz, G. Want a Great New Idea? Don't Ask Your Customers. The GAB. Finweek, 27 February 2014; $24-25$.

17. Surowiecki, J. The Wisdom of Crowds; Anchor Books: New York, NY, USA, 2004.

18. Nambisan, S.; Baron, R.A. Virtual Customer Environments: Testing a Model of Voluntary Participation in Value Co-creation Activities. J. Prod. Innov. Manag. 2009, 26, 388-406. [CrossRef]

19. Kijkuit, B.; Ende, J.V.D. The Organizational Life of an Idea: Integrating Social Network, Creativity and Decision-Making Perspectives. J. Manag. Stud. 2007, 44, 863-882. [CrossRef] 
20. Oinonen, M. Customer Engagement Practices in Business-to-Business Companies Operating in Finland. Competitive Paper for the 31th Annual IMP Conference. University of Southern Denmark. 2015. Available online: https://www.impgroup.org/uploads/papers/8498.pdf (accessed on 7 July 2019).

21. Harris, L.V.A. Idea Engineering: Creative Thinking and Innovation; Momentum Press: New York, NY, USA, 2014.

22. Garbuio, M.; Dong, A.; Lin, N.; Tschang, T.; Lovallo, D.; Tschang, F. Demystifying the Genius of Entrepreneurship: How Design Cognition Can Help Create the Next Generation of Entrepreneurs. Acad. Manag. Learn. Educ. 2018, 17, 41-61. [CrossRef]

23. Alwattari, A. Innovation Strategy: Does Your New Product Idea Really Solve a Customer Problem? Innovation Management. 16 July 2004. Available online: https://innovationmanagement.se/imtool-articles/innovationstrategy-does-your-new-product-idea-really-solve-a-customer-problem/ (accessed on 10 February 2019).

24. Witt, U. What kind of innovations do we need to secure our future? J. Open Innov. Technol. Mark. Complex. 2016, 2, 17. [CrossRef]

25. Forbes. 50 Most Engaged Companies. Forbes Insights with PEGA. 2017. Available online: https: //www.forbes.com/insights/50-most-engaged-companies/\#1b4607262dfa (accessed on 11 February 2019).

26. Rather, R.A.; Hollebeek, L.D.; Islam, J.U. Tourism-based customer engagement: The construct, antecedents, and consequences. Serv. Ind. J. 2019, 39, 519-540. [CrossRef]

27. Kesgin, M.; Murthy, R. Consumer engagement: The role of social currency in online reviews. Serv. Ind. J. 2019, 39, 609-636. [CrossRef]

28. Altinay, L.; Poudel, S. Enhancing Customer Experience in the Service Industry: A Global Perspective; Cambridge Scholars Publishing: Newcastle upon Tyne, UK, 2016.

29. Altinay, L.; Saunders, M.N.K.; Wang, C.L. The Influence of Culture on Trust Judgments in Customer Relationship Development by Ethnic Minority Small Businesses. J. Small Bus. Manag. 2014, 52, 59-78. [CrossRef]

30. Chesbrough, H.W. Open Innovation: The New Imperative for Creating and Profiting from Technology; Harvard Business School Press: Boston, MA, USA, 2003.

31. Yun, J.J.; Won, D.; Park, K. Dynamics from open innovation to evolutionary change. J. Open Innov. Technol. Mark. Complex. 2016, 2, 7. [CrossRef]

32. Yun, J.J.; Jeon, J.; Park, K.; Zhao, X. Benefits and Costs of Closed Innovation Strategy: Analysis of Samsung's Galaxy Note 7 Explosion and Withdrawal Scandal. J. Open Innov. Technol. Mark. Complex. 2018, 4, 20. [CrossRef]

33. Cooper, R.G.; Edgett, S.J.; Kleinschmidt, E.J. Optimizing the stage-gate process: What best practice companies do, Part I. Res. Technol. Manag. 2002, 45, 21-27. [CrossRef]

34. Oganisjana, K. Starpdisciplinārās Mācības Uzṇēmības un Uznēēējspējas Veicināšanai (Interdisciplinary Teaching and Learning for Promoting Entrepreneurship). 2015. Available online: http://sf.viaa.gov.lv/library/ files/original/K_Oganisjanas_monografija_2015_ASEM.pdf (accessed on 7 July 2019).

35. Oganisjana, K.; Laizans, T. Opportunity-Oriented Problem-Based Learning for Enhancing Entrepreneurship of University Students. Procedia Soc. Behav. Sci. 2015, 213, 135-141. [CrossRef]

36. Tracy, B. Creativity and Problem Solving. The Brian Tracy Success Library; AMACOM: New York, NY, USA, 2014.

37. Amazon. Spill Stopper, Lid Cover. Available online: https://www.amazon.com/AUANDYU-StopperSafeguard-Silicone-Multi-Function/dp/B0748H2XXX (accessed on 24 January 2019).

(C) 2019 by the authors. Licensee MDPI, Basel, Switzerland. This article is an open access article distributed under the terms and conditions of the Creative Commons Attribution (CC BY) license (http://creativecommons.org/licenses/by/4.0/). 